INTERNATIONAL JOURNAL OF MULTidisciplinARY RESEARCH AND ANALYSis

ISSN(print): 2643-9840, ISSN(online): 2643-9875

Volume 05 Issue 01 January 2022

DOI: 10.47191/ijmra/v5-i1-16, Impact Factor: 6.072

Page No.- $118-127$

\title{
The Influence of Online Marketing on Marketing Performance of Small and Medium Scale Businesses in Akwa Ibom State Nigeria
}

\author{
Clement Udowong Eke \\ University of Cross River State, Nigeria
}

\begin{abstract}
Online marketing entails carrying out marketing activities with the use of internet-based application. The main objective of the study was to ascertain the relationship between online marketing and marketing performance of small and medium scale enterprises in Akwa Ibom State. The sample consisted of 366 SMEs operators across the three senatorial districts in Akwa Ibom State. Survey research design was adopted by the researcher. Data were collected with the use of structured questionnaire. Two hypotheses were formulated tested and analyzed using the simple linear regression. It was discovered that there is significant relationship between the two proxies of online marketing and marketing performance of small and medium scale enterprises in Akwa Ibom State. In line with the findings, the researchers concluded that e-mail marketing and search engine marketing does enhance marketing performance of micro, small and medium scale enterprises in Akwa Ibom State. The researcher further recommended SMEs that have not been using these dimensions to a large extent should do so in order to be competitive and enhance their performance.
\end{abstract}

KEYWORDS: Online marketing, marketing performance, small and medium scale enterprises

\section{INTRODUCTION}

Online marketing is a subset of electronic marketing which requires a live internet connection for it to function. Internet has become a remarkable significant vehicle in marketing and is gradually becoming a front-end application of intelligence of the customers and as well as their purchase applications. El-Gohary (2010) opined that online marketing is a recent innovation and a current business practice that is concern with marketing goods, services, ideas and concepts with the use of electronic measures such as internet, mobile phones, extranets and intranets.

According to Wilson and Makau (2017), online marketing is a business effort to inform, converse, promote and goods and services over the Internet. Online marketing attempts to reach out to numerous existing and potential customers through the Internet at a shortest possible time. Coviello et al (2001) opined that online marketing as an innovative technology-based activity, has been considered as one of the projecting aspects of marketing practice that has to do with the use of internet and other communicating technologies to build and facilitate dialogue between a business and its customers. Online marketing is not just traditional marketing using the digital technology tools but it's a strategic model to achieve brand value, two way communications and provide customer satisfaction. The idea of online marketing denotes a type of marketing in which marketing objectives are achieved through the use of electronic communication tools like internet, interactive TV and mobile phones.

On the other hand, marketing performance is the application of scarce resources by companies to meet the demand of customers for market related goals such as profit margin, market share, and sales volume among others (Gakii and Maina 2019). Indicators of marketing performance include market share, total sales, customer satisfaction and customer acquisition (Gunday et al., 2012; Rashid, 2008; Sullivan and Dooley, 2009). Further, measuring marketing performance allows businesses to align her marketing strategies accordingly, increase their competitive advantage and to avert or outsmart the marketing strategies of their competitors.

SMEs are a group of business entities that cut across all the sector of the economy and form the bulk of economic activities in Nigeria's economy. . Ekpo et at. (2017) identifies the unique characteristics of SMEs to include small scale operations, ease of entry into the economic activities and reliance on indigenous resources. The quantitative definition on the other hand focuses more explicitly on quantitative characteristics such as number of employees, value of sales and/or value of assets. Ajagu (2005) reported that Small and medium scale enterprises are engines of growth in any economy and a veritable tool for the 


\section{The Influence of Online Marketing on Marketing Performance of Small and Medium Scale Businesses in Akwa Ibom State Nigeria}

development of indigenous technology, rapid industrialization, generation of employment and a key driver of sustainable economic development in Nigeria and also they occupy a place of pride in every country or state. It is also noted that the small and medium scale enterprises are the main driving force behind poverty alleviation, wealth creation, income distribution and reduction in income disparities and promoting self-experience (Aremu, 2004). Ogechukwu et al (2013) also opined that SMEs constitute the fountain head of essentiality for the Nigeria economy and their problems have been noticed as those of the nation by virtue of their diversity, number, penetration in all sectors of the economy and marketing contribution to employment and to the success of the particular areas in which they operate.

\subsection{Statement of problem}

Despite the increased use of the internet and the fact that online marketing has proven advantageous to Multinational companies like Coca-cola or Unilever, SMEs are seen to take a slow pace in adopting this strategy in their operations. Some previous studies have shown that this problem is as a result of the fact that most of the operators of Small and Medium Scale Enterprises are less informed about the modern practice and strategy of marketing. Furthermore, to the best knowledge of the researcher, no empirical evidence has been seen on the relationship between online marketing and marketing performance of small and medium scale enterprises in Akwa Ibom State. It is on this background that this study was set out.

\subsection{Objectives of the study}

The main objective of the study was to ascertain the relationship between online marketing and marketing performance of small and medium scale enterprises in Akwa Ibom State. The specific objectives were to:

i) To determine the relationship between e-mail marketing and marketing performance of small and medium scale enterprises in Akwa Ibom State

ii) To examine the relationship between search engine marketing and marketing performance of small and medium scale enterprises in Akwa Ibom State.

\subsection{Research questions}

i. What is the relationship between e-mail marketing and marketing performance of small and medium scale enterprises in Akwa Ibom State?

ii. What is the relationship between search engine marketing and marketing performance of small and medium scale enterprises in Akwa Ibom State?

\subsection{Research hypotheses}

$\mathrm{H}_{01}$ : there is no significant relationship between e-mail marketing and marketing performance of small and medium scale enterprises in Akwa Ibom State.

Ho2: $\quad$ there is no significant relationship between search engine marketing and marketing performance of small and medium scale enterprises in Akwa Ibom State.

\section{REVIEW OF RELATED LITERATURE}

\subsection{Concept of online marketing}

Online marketing has developed since the 1990s and 2000s and has changed the way brands and businesses utilize technology and internet for their business operations. Online marketing became more sophisticated in the 2000s and 2010s. Online marketing campaigns are rapidly becoming more popular and efficient as digital platforms are increasingly incorporated into marketing plans as many people use digital devices instead of going to their physical shops (Barron and Copeland, 2012). Online marketing techniques such as search engine optimization, search engine marketing, content marketing, influencer marketing, content automation, campaign marketing, social media marketing, social media optimization, e-mail direct marketing, display advertising, data-driven marketing and e-commerce marketing are becoming more and more common in our advancing technology (Babalola and Babalola, 2013).

Smith and Chaffey (2005) recognized that online marketing enhanced customer relations through activities that aid exchange of ideas, goods and services to satisfy both parties. Dury (2008) also affirm that the concept is not only about delivering the message but that online marketing enables receiving and exchanging perceptions in a short periods of time. Wilson and Makau (2017) agreed that online marketing offered businesses access to new market, as well as increased openings outside geographical boundaries thereby restricted international entry hitches. Early adopters of online marketing have gained a competitive advantage and reputable customer loyalty programs that have made them retain as well as get new clients (Sparkes and Thomas, 2001) as cited in Wilson and Makau (2017). 


\section{The Influence of Online Marketing on Marketing Performance of Small and Medium Scale Businesses in Akwa Ibom State Nigeria}

\subsection{Proxies of Online Marketing}

- Email marketing: E-mail is the abbreviation for electronic mail. According to Babalola and Babalola (2013), email is the most personal advertising medium among all other forms of e-marketing tools in history. E-mail Marketing is a method of transmitting text files, photos, audio and video files from one computer to another through the internet. E-mail enables computer users to send messages and data quickly through a local area network and beyond through the internet. E-mail came into existence in the 1990s and has become a welcome development in business and personal communications. E-mail has made a great impact on the number of information sent worldwide. It has become an important method of sending and receiving information previously via regular mail, telephone, courier, fax, television and radio.

The use of e-mail is one of the most efficient methods of communication. Crystal (2006) stated that e-mail is the use of computer systems to transfer messages between users and that knowing how to use e-mail is an essential skill in businesses today. It is already commonly used in the corporate world and people use it every day. E-mail is also widely used in day to day activities as well as in business transaction, for example, online business, face-to-face business and in wider business environments. E-mail software transfers messages through the internet to a recipient's computer where it is placed in the particular mailbox and the recipient uses an e-mail application to view and reply to the messages, as well as to delete or save it. Because e-mail is a convenient and inexpensive form of communication, it has dramatically added value to personal and business communication.

\section{- $\quad$ Search Engine Marketing (SEM)}

Search engine is a web software program or web based script available over the Internet that searches documents and files for keywords and returns the list of results encompassing those keywords (Gurneet 2017). Google, Yahoo, Bing, AOL, Baidu are among the topmost search engines of the world and account for most of the Internet traffic. Google accounts for over $69.80 \%$ of all global desktop search traffic, followed by Bing at 13.31\%, Baidu at 12.53\% and Yahoo at 2.11\% (Net Market Share, 2017).

Search engine marketing (SEM) has become an important strategic tool for online marketing. Most firms utilize an informal SEM strategy, where Website optimization is perceived most effective in attracting traffic (Barry and Charleton, 2009). SEM has emerged as one of the main method companies use to successfully increase the visibility of their Website. According to Jalang'o (2015) Search Engine Marketing refers to the process where companies pay to have their adverts on search engines and this happens when companies buy certain keywords that relate to their business and their adverts show up when users search the keywords they have paid for. However, businesses that use SEM pay for these adverts only when users click on their adverts. This is known as pay-per-click (PPC). Additionally companies can utilize classified adverts on websites that specializes on specific services such as car sales, real estate, hiring and beauty to promote their goods and services.

Colborn (2005) opined that Search engine marketing is the application of tactical elements linked with the search engines and manipulated to form a strategy to attain online goals. Search engine marketing is directly associated with search engines and can be described as an exercise in the marketing of the website through search engines. SMEs and companies especially those who owns website, welcomes search engine marketing because it offers information and possibility to attract a huge number of customers. The major search engines are Google, Yahoo, Wikipedia, Bing Search, among other.

\subsection{Concept of Marketing Performance}

It has long been recognized that marketing performance is essential to overall business performance, as well as amongst SMEs (Langerac 2003; Kara, et al. 2005). This essentiality is being manifested in indicators such as strong brand awareness, expressions of consumer preference sales volume, and high levels of market share (Grønholdt and Martensen, 2006). However, it is conventionally assumed that achievement of robust marketing performance is problematic for small businesses because of their distinctive features compared with large businesses (Blankson and Cheng, 2005). According to Gakii and Maina (2019) marketing performance is the utilization of scarce resources by businesses to meet the demand of consumers for market related goals such as market share, profit and sales volume.

Since a substantial amount of money, time and effort is spent on marketing activities, it is needful for the marketing department to show the effects of their efforts on the company's overall performance (Kithinji, 2014). These effects are usually measured using the number of sales or sales volume, profit margin, number of website visitors, customer's brand awareness levels and market share.

\section{Indicators of Marketing Performance Competitiveness}

Competitiveness of a company means adapting its goods or services to the market and competition requirements, particularly in terms of quality, product range, price as well as optimal sales channels and methods of promotion (Siudek and 


\section{State Nigeria}

Zawojska, 2014). Chao-Hung and Li-Chang (2010) also opined that a firm's competitiveness is its economic strength against its rivals in the marketplace where goods, services, people and innovations move freely despite the geographical boundaries. Some businesses looks at competitiveness as the ability to persuade consumers to select their offerings over alternatives while others opine that competitiveness is the ability to expand continuously process capabilities.

\section{Sales Volume}

Sales volume refers to the number of items sold by a firm over a specific period of time such as fiscal quarter or a year (Ndikubwimana 2016). Kelemu and Mandefro (2017) opined that the essence of sales volume and market share are prominent in many businesses and that the firm performance and profit of the firm can be summarized in sales volume. One of the crucial goal of firms is to boost sales volume and market share to attain greater scale in its processes and advance profitability and due to this fact, managers always seek to increase their market share.

To boost revenue and hit growth, a firm must continually increase sales volume by all means. Understanding your sales volume can tell you what goods or services that is selling and the once that are not selling. There are also different ways that company can use to influence her volume increase and one of it is the adoption of contemporary marketing strategy.

\subsection{Small and Medium Scale Enterprises}

SMEs are a group of business entities that cut across all the sector of the economy and form the bulk of economic activities in Nigeria's economy. Various terminologies found in literature such as small and medium scale enterprises, micro, small and medium scale enterprises, small and medium-sized enterprises, small and medium enterprises are used interchangeably to describe this group of businesses. SMEs may be viewed in terms of their qualitative and quantitative features. The qualitative definition tries to identify the certain features which are more peculiar to small businesses than large businesses. Ekpo et at. (2017) identifies the unique characteristics of SMEs to include small scale operations, ease of entry into the economic activities and reliance on indigenous resources. The quantitative explanation on the other hand centers more explicitly on quantitative features such as number of employees, value of sales among others.

SMEs in Nigeria are not devoid of problems. Ebitu (2016) opined that this enterprise faces problems such as inadequate capital, incompetent management, fraud, and production problems. Ebitu et al (2015) revealed that in the southern region of Nigeria, marketing issues such as difficulty in managing businesses, advertising, lack of adequate marketing research, ignorance of competition, advertising, poor branding and packaging, poor market analysis, meager promotion, poor segmentation and poor pricing technique contribute adversely in affecting SMEs' profit margin and sales volume.

Dzisi and Ofosu (2014) posits that though SMEs experience difficulties in absorbing and coping with obstacles, they need to cultivate the ability to deal with the ever increasing challenges in the global market (Leopoulos, 2006). As a step, small and medium scale enterprises should initiate marketing strategies and tactics that can aid them take decisions on a number of variables to influence mutually-satisfying exchange transactions and relationships (Taiwo, 2010).

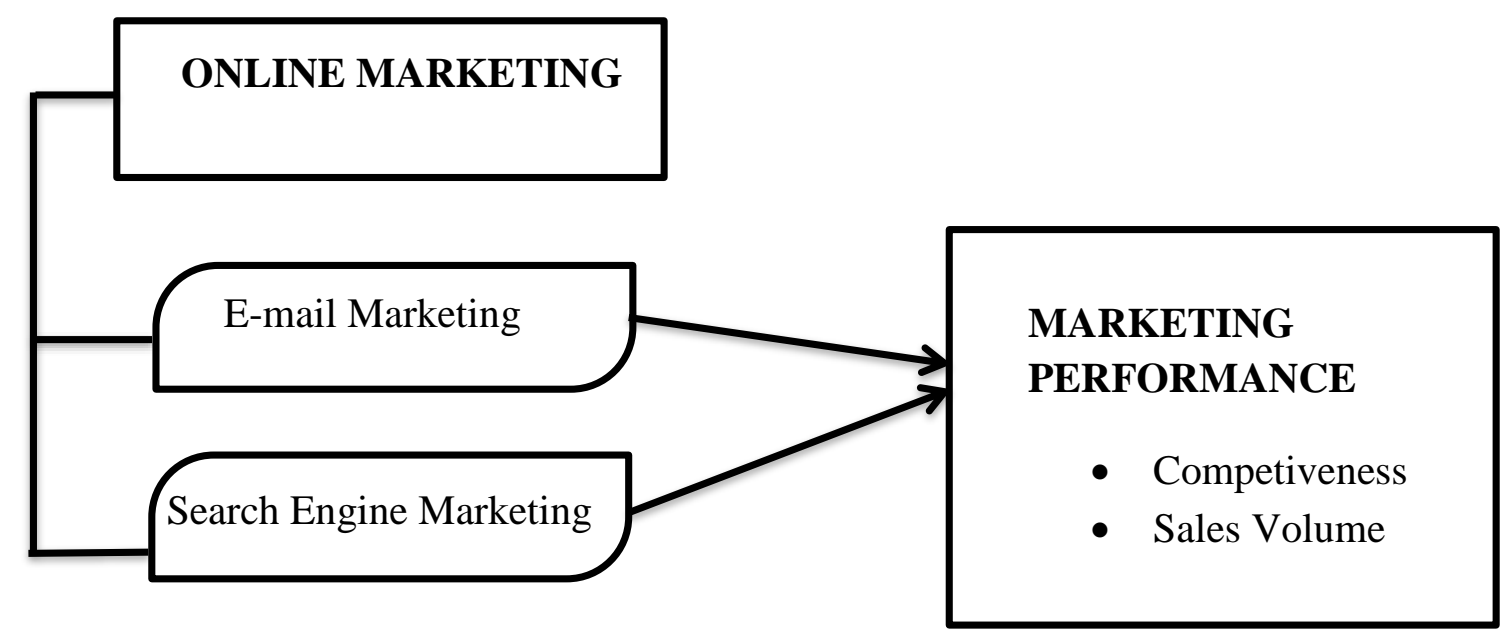

Figure 2.1. Conceptual Framework of Online Marketing and Marketing Performance of Small and Medium Scale Enterprises in Akwa Ibom State.

Source: Researcher's Model 


\section{The Influence of Online Marketing on Marketing Performance of Small and Medium Scale Businesses in Akwa Ibom State Nigeria}

\subsection{Theoretical Framework}

This work is based on Innovation Diffusion Theory by Rogers, (1962). The theory states that individuals and organizations do not adopt innovations at the same pace but maintains that the earlier a person adopt new technology, the better for them. The four key elements of the theory are: innovation, communication channels, time and social change. Innovations here may include new technology or new idea and the adopters may be individual or businesses. There are a number of studies that used the IDT as its theoretical framework or combined the IDT with other theories and models to explain ICT adoption and use.

The justification of adopting this theory lies in its relevant to the independent variable (Online marketing) the theory identifies the essentiality of internet-based communication tool such as E-mail, Search engine, among others, in business. The theory illuminates the fact that full application and usage of online marketing dimensions, inevitably occupies a vital place in an organization.

\subsection{Empirical review}

Kithinji (2014) carried out a study on internet marketing and performance of Small and Medium Scale Enterprises in Nairobi. The objective of the study was to establish the extent of internet marketing application by SMEs in Nairobi. The study was descriptive in nature and used a sample size of 90 SMEs. Primary data was collected with the use questionnaires from the top management of these SMEs. The collected data was analyzed using frequencies, percentages, means and standard deviation as well as factor and multiple regression analysis. It established that the usage of online marketing was moderate and that the SMEs faced financial and technological challenges in the adoption of internet marketing. The study also revealed that Social media and websites were the most popular e-marketing strategies and their usage led to increased revenues, increase in market share, competitive advantage and growth; additionally, the loyalty of their customers increased and the SMEs were able to penetrate new markets.

Achieng (2016) carried out a study on how SMEs are using online marketing to improve their competitiveness in Kenya with a case study of Tembea East Africa Safaris. The purpose of the study was to investigate how small and medium enterprises are utilizing online marketing strategy to advance their competitiveness in Kenya. The study used a descriptive research design and the target population 103. Data for the study was collected with the use of questionnaire. The data was subjected to analysis using multiple regression, percentages, means, standard deviation inferential statistics. The study showed that the company owners perceive online marketing as an important function of the business. The study established that Tembea Kenya Safaris used online advertising to promote their travel packages to potential clients. The researcher recommended that managers should encourage online marketing to improve their customer base, increase their competitive advantage and co-ordinate their activities.

\section{METHODOLOGY}

The research method is as follows:

Research design: The researcher adopted survey research design as the key research design. This is because survey design permits information to be gathered from a sample of people or organizations by the use of questionnaire.

Study area: The study was conducted in Akwa Ibom State, Nigeria. It is situated in the coastal southern part of the country. The state is located in the South-South geopolitical zone, and is bordered on the east by Cross River State, on the west by Rivers State and Abia State, and on the south by the Atlantic Ocean

Population of the study: The population of the study comprised all registered small and medium scale enterprises in Akwa Ibom and it is stated as follows:

Table 3.1 Population of SMEs in the three senatorial district of Akwa Ibom State

\begin{tabular}{lll}
\hline Senatorial district & Population & Percentage \\
Uyo & 4,396 & $40 \%$ \\
Eket & 3,357 & $28 \%$ \\
Ikot Ekpene & 3,837 & $32 \%$ \\
Total & 11,990 & $100 \%$ \\
\hline
\end{tabular}

Source: Directorate of SMEs Akwa Ibom State, (2021)

\section{Sample Size Determination:}

Being a finite population, Taro Yamane formula was used to determine the sample size for the study. The formula is stated as follows: 
The Influence of Online Marketing on Marketing Performance of Small and Medium Scale Businesses in Akwa Ibom State Nigeria

$$
\mathrm{n}=\frac{N}{1+N(e) 2}
$$

Where:

$\begin{array}{lll}\mathrm{n} & = & \text { sample size } \\ \mathrm{N} & = & \text { population } \\ \mathrm{e} & = & \text { error limit (0.05 on the basis of } 95 \% \text { confidence level) } \\ \text { Mathematically, } & \end{array}$

$$
\begin{aligned}
& n= \frac{11,990}{1+11,990(0.05)^{2}} \\
&= \frac{11,990}{1+11,990(0.0025)} \\
& \frac{11,990}{1+29.975} \\
& \frac{11,990}{30,975}
\end{aligned}
$$$$
n=387
$$

Sampling Techniques: A total of 387 SMEs operators were selected using simple random technique. This technique was adopted in order that all items in the population will be given an equal opportunity of participating in the study. The breakdown is as follows:

Table 3.2 Questionnaire Distribution per Senatorial District in Akwa Ibom State

\begin{tabular}{lll}
\hline Senatorial district & Number of SMEs operators & Percentage \\
\hline Uyo & 155 & $40 \%$ \\
Eket & 108 & $28 \%$ \\
Ikot Ekpene & 124 & $32 \%$ \\
Total & 387 & $100 \%$ \\
\hline
\end{tabular}

Source: Researcher's Computation (2021)

Uyo senatorial district was allocated the highest copies of questionnaire because from the data gotten from the Directorate of SMEs Akwa Ibom State, the senatorial district has the highest number of SMEs in the state. It was followed by Ikot Ekpene and Eket senatorial district respectively.

Sources of Data: Primary data was the main source of data for the study. This primary data was collected from the operators of small and medium scale enterprises in Akwa Ibom State.

Research instrument: Research questionnaire tagged: “E-marketing and Marketing Performance of Small and Medium Scale Enterprises Questionnaire (EMMPSME)" was used for the study. The instrument sought to investigate the relationship between Online marketing and Marketing performance of Small and medium scale enterprises in Akwa Ibom State.

Data collection method: The research instrument used in collecting data was five (5) point Likert scale questionnaire which is stated as follows: Strongly agree (5), Agree (4), Undecided (3), Disagree (2), strongly disagree (1). The questionnaire was selfadministered

Administration of Research Instrument: The researcher could not be at all locations at the same time, help was sought in administering the instrument to the respondents within the research period

Reliability of the Instrument: A trial test of the instrument was conducted using 40 SMEs operators. The internal consistency of the instrument was determined using Cronbach's Alpha method to establish reliability coefficient. The coefficient alpha for all dimensions used for this study were presented as follows: 
The Influence of Online Marketing on Marketing Performance of Small and Medium Scale Businesses in Akwa Ibom State Nigeria

Table 3.3 Cronbach's Alpha Result

\begin{tabular}{lll}
\hline Variables & No. of Items & Reliability coefficients \\
\hline Email marketing & 4 & 0.633 \\
Search engine marketing & 4 & 0.563 \\
Marketing performance & 3 & 0.623 \\
\hline
\end{tabular}

Source: Researcher's Computation (2021)

The reliability result was rationally high and therefore the reliability of the instrument was justified.

Data Analysis Techniques: Simple linear regression analysis was used to examine the extent of the relationship between the independent variables (e-mail marketing, search engine marketing) and the dependent variable (marketing performance). The two hypotheses were tested separately at 0.05 level of significance.

\section{Model Specification}

Marketing performance was estimated as a direct function of some electronic marketing proxies (online marketing and search engine marketing)

This can be expressed in functional equation form as;

$\mathrm{Y}=\mathrm{F}\left(\mathrm{X}_{1}, \mathrm{X}_{2}\right)$

Recoded to represent the variables, it is presented as;

$\mathrm{MP}=\mathrm{F}(\mathrm{Em}, \mathrm{Se})$

The simple regression model representing the relationship that exists between each independent variables $\left(X_{1}, X_{2},\right)$ and the dependent variable $(Y)$ was expressed in this form;

$H_{01}: Y=a_{0}+b_{1} x_{1}+e$

$H_{02}: Y=a_{0}+b_{2} X_{2}+e$

To represent the variables in use, the simple linear regression equations were presented as:

$\begin{array}{ll}H_{01}: M p=a_{0}+b_{1} E m+ & e \\ H_{02}: M p=a_{0}+b_{2} S e+ & e\end{array}$

Where: $\mathrm{Mp}(\mathrm{Y}) \quad$ = Marketing performance

$\operatorname{Em}\left(X_{1}\right)=\quad$ Search engine marketing

$\operatorname{Se}\left(X_{2}\right)=$ Search engine marketing

e $=$ errorterm

The above estimated equations are linear function which was used in testing the model separately.

\section{RESULT OF DATA ANALYSIS}

A total of three hundred and eighty seven (387) copies of questionnaire were circulated and three hundred and seventy one (370) were recovered of which three hundred and sixty six (366) copies were found functional. This gives a response rate of 95.8 percent. Only 94 percent of the administered questionnaire was found useable. The responses were coded and the Statistical Package for Social Sciences was used to run data analysis.

Table 4.1. Summary of Simple Regression Showing the Relationship between Email and marketing performance

\begin{tabular}{|c|c|c|c|c|c|}
\hline & $\mathbf{B}_{1}$ & SE & $\mathbf{B}_{\mathbf{2}}$ & t-value & Significant ( 2 tailed) \\
\hline Constant & 6.200 & 0.544 & - & 11.406 & 0.000 \\
\hline Email marketing & 0.345 & 0.036 & 0.447 & 9.544 & 0.000 \\
\hline \multicolumn{6}{|c|}{ Dependent variable: Marketing performance } \\
\hline \multicolumn{6}{|c|}{$R=0.447^{\mathrm{a}}$} \\
\hline \multicolumn{6}{|c|}{$R^{2}=0.200$} \\
\hline \multicolumn{6}{|c|}{ Adjusted R-square $=0.198$} \\
\hline \multicolumn{6}{|c|}{ Std. Error of estimate $=1.59950$} \\
\hline \multicolumn{6}{|l|}{$F=91.093$} \\
\hline Significance $=0.000$ & & & & & \\
\hline
\end{tabular}

Source: Researcher's Computation (2021) 

State Nigeria

Table 4.1 shows $R^{2}$ of 0.200 which means that the independent variable (Email marketing) accounted for $20 \%$ of the variation in marketing performance. In addition, the significant F-ratio at $F=91.093, p<0.000$ suggest that the results of the regression model could not have occurred by chance and that the independent variables significantly predicted the dependent variable.

To assess the importance of the independent variable in determining the degree of change in the dependent variable, the beta coefficients for the variable; Email marketing $X_{1}(E m)$ had statistically significant standardized coefficient of $\beta=0.345$, Sig $=0.000$, showing a positive significant influence on marketing performance. This finding can be interpreted that every 1 -unit change in email marketing will lead to 0.345 change in marketing performance. Since the $p$-value is less than 0.05 ( $p=0.000<0.05$ ), the null hypothesis is rejected. Therefore, there is significant positive relationship between email marketing and marketing performance.

$$
\begin{aligned}
& Y=a 0+\beta_{1} x_{1}+\ldots . . . e \\
& M p=a_{0}+\beta_{1} E m+\ldots \ldots . e \\
& \text { Thus to justify the simple linear regression equation, the resulting equation is: } \\
& M p=6.200+0.345 \mathrm{Em}
\end{aligned}
$$

Table 4.2 Summary of Simple Regression Showing the Relationship between Search engine marketing and marketing performance

\begin{tabular}{llllll}
\hline & $\mathbf{B}_{\mathbf{1}}$ & SE & $\mathbf{B}_{\mathbf{2}}$ & t-value & Significant (2 tailed) \\
\hline Constant & 5.398 & 0.645 & - & 8.370 & 0.000 \\
Search engine marketing & 0.395 & 0.043 & 0.437 & 9.270 & 0.000 \\
$\begin{array}{l}\text { Dependent variable: Marketing performance } \\
\mathrm{R}=0.437^{\mathrm{a}}\end{array}$ & & & & & \\
$\mathrm{R}^{2}=0.191$ & & & & \\
Adjusted R-square $=0.189$ & & & & \\
Std. Error of estimate $=1.60866$ & & & & \\
$\mathrm{~F}=85.926$ & & & & \\
\hline
\end{tabular}

Significance $=0.000$

*significantly related at $5 \%(p<0.05)$. $B_{1}=$ unstandardized beta, $B_{2}=$ standardized beta, $S E=$ standard error.

Source: Researcher's Computation (2021)

Table 4.2 shows $\mathrm{R}^{2}$ of 0.191 which means that the independent variable (Search engine marketing) accounted for $19.1 \%$ of the variation in marketing performance. In addition, the significant F-ratio at $F=85.926, p<0.000$ suggest that the results of the regression model could not have occurred by chance and that the independent variables significantly predicted the dependent variable.

To assess the importance of the independent variable in determining the degree of change in the dependent variable, the beta coefficients for the variable; Search engine marketing $X_{3}$ (Se) had statistically significant standardized coefficient of $\beta=$ 0.395 , Sig $=0.000$, showing a positive significant influence on marketing performance. This finding can be interpreted that every 1 -unit change in search engine marketing will lead to 0.395 change in marketing performance. Since the $p$-value is less than $0.05(p=0.000<0.05)$, the null hypothesis is rejected. Therefore, there is significant positive relationship between search engine marketing and marketing performance.

$$
\begin{aligned}
& Y=a 0+\beta_{1} x_{3+} \quad e \\
& M p=a_{0}+\beta_{3} S e+e
\end{aligned}
$$

Thus to justify the simple linear regression equation, the resulting equation is:

$\mathrm{Mp}=5.398+0.395 \mathrm{Se}$

\section{DISCUSSION OF THE FINDINGS}

Findings of the study shows that there is a significant positive relationship between the two proxies of online marketing (e-mail marketing, search engine marketing) and marketing performance of small and medium scale enterprises in Akwa Ibom state.

The result of the first hypothesis indicate that e-mail marketing influences marketing performance of small and medium scale enterprises in Akwa Ibom State with a regression coefficient of 0.345. This result is in agreement with that of Kithinji (2014) who found out that e-mail marketing is one of the key drivers of business performance. 


\section{The Influence of Online Marketing on Marketing Performance of Small and Medium Scale Businesses in Akwa Ibom State Nigeria}

The result of the second hypothesis also shows a regression coefficient of 0.395 which means that there is a strong positive relationship between search engine marketing and marketing performance of small and medium scale enterprises in Akwa Ibom State. This result is in tandem with that of Wanjau (2011) who found that there is a strong positive relationship between search engine marketing and sales volume.

\section{CONCLUSION}

The findings of the study clearly show that embracing online dimensions does improve marketing performance. The empirical results of the study clearly highlight the following:

This study has revealed that those SMEs in Akwa Ibom State who are keen in adopting online marketing and integrating it into their business strategies, have achieved above average business performance and have sustainably transformed their businesses by synchronizing their customers, business processes and technology to profitably achieve growth in the dynamic and competitive business environment.

Email and search engine marketing are all key dimensions of online marketing which enhances the marketing performance of SMEs that are keen on realizing the benefits of online marketing.

\section{RECOMMENDATIONS}

i. SMEs that have not been using Email marketing to a large extent should do so in order to be competitive and enhance their performance.

ii. Advertising campaign should be emphasized more on search engine since a good number of the population makes us of this platform.

\section{REFERENCES}

1) Achieng, B. (2016). How SMEs are using online marketing to improve their competitiveness in Kenya: A case study of Tembea East Africa Safaris. Phd (ed) dissertation, United States International University-Africa, 97p.

2) Ajagu, A. (2005). SMls Do not enjoy form of incentive, Business day, Business day media Ltd, Lagos, Nigeria, 61p.

3) Babalola, O. and Babalola, G. (2013). E-Marketing tools and small and medium enterprises in Nigeria. Journal of Business Administration and Management, 2(1): 386-411.

4) Baron, R. and Copeland, G. (2012); Social Network: A Brand View of Challenges and Opportunities, Harvard Duesto Marketing, Norway, 56p.

5) Chao-Hung W, Li-Chang H. (2010). The influence of dynamic capability on performance in the high technology industry: The moderating roles of governance and competitive posture. African Journal of Business Management, 4(5): 562-577.

6) Coviello, N.E., Milley, R., and Marcolin, B. (2001). Understanding IT-enabled interactively in contemporary marketing. Journal of interactive marketing, 15(4): 18-33.

7) Crystal, D. (2006). Language and the internet. Cambridge university press. United Kingdom, 81p.

8) Drury, G. (2008). Opinion piece: social media: should marketers engage and how can it be done effectively? Journal of Direct, Data and Digital Marketing Practice, 11(9): 274-277

9) Dzisi, S. and Ofosu, D. (2014). Marketing strategies and the performance of SMEs in Ghana. European Journal of Business and Management, 6 (5): 102-111

10) Ebitu E. T. (2016). Marketing strategies and the performance of small and medium enterprises in Akwa Ibom State, Nigeria. British Journal of Marketing Studies, 4 (5): 51-62

11) Ebitu, E. T., Basil, G. and Ufot, J. A. (2015). An appraisal of Nigeria's micro, small and medium enterprises (MSMEs): growth, challenges and prospects. International Journal of Small Businesses and Entrepreneurship Research, 6(3): $15-29$.

12) Ekpo, N., Udoidem, J. and Acha, I. (2017). Growth Performance Vis-à-vis Enterprises Size: A study of SMEs in Akwa Ibom State Nigeria. Account and Financial Management Journa, 2(1): 582-591

13) El-Gohary, H. (2010). E-Marketing: A literature review from a small business's perspective. International Journal of Business and Social Science, 1(1): 214-244.

14) Gakii A. and Maina S. (2019). Nexus between online marketing strategies and marketing performance: a critical review of related literature and research agenda. European Journal of Business and Management. 11(15): 99-107.

15) Gunday, G., Ulusoy, G., Kilic, K. and Alpkan, G. (2012). Effects of innovation types on firm performance. Science Direct.com, $13 p$. 
The Influence of Online Marketing on Marketing Performance of Small and Medium Scale Businesses in Akwa Ibom State Nigeria

16) Gurneet K. (2017). Role and importance of search engine optimization. International Journal of Research Granthaalayah, 5(6): 147-151

17) Jalang'o, B. O. (2015). Effect of digital advertising on the performance of commercial banks in Kenya. Phd (ed) dissertation, School of Business, University of Nairobi, 121p.

18) Kara, A., Spillan, J. and DeShields, O. (2005). The effect of a market orientation on business performance: a study of smallsized service retailers using MARKOR scale, Journal of Small Business Management, 43(2): 105-118

19) Kelemu, N and Mandefro, G. (2017). The role of marketing strategy for sales volume: a case study on Ethiopian textile firms, Ethiopia. Journal of Marketing and Consumer Research, 40(13): 332-341

20) Kithinji L. (20014). Internet Marketing and Performance of Small and Medium Scale Enterprises in Nairobi. M.sc (ed) dissertation, University of Nairobi, Kenya, 69p.

21) Langerac, F. (2003). The effect of market orientation on potential advantage and organisational performance. Journal of Strategic Marketing, 11(2): 93- 115.

22) Ndikubwimana P. (2016). The effect of marketing mix on sales volume of SMEs in rwanda: case study of kimironko commercial center. 2016 cik-auc confetrence. entrepreneurship, responsible management and economic development. $154 p$.

23) Ogechukwu D., Oboreh J,, Umukoro F and Uche A. (2013). Small and medium scale enterprises in nigeria, the marketing interface. Global Journal of Management and Business Research. 13(14): 234-266

24) Rashid, S. (2008). Impact of organizational culture on customer satisfaction: a study of practitioners in public relation and corporate communication industry in malaysia. unpublished thesis, international islamic university Malaysia, Kuala Lumpur, $96 \mathrm{p}$.

25) Rogers, E. (1962) Diffusions of innovations. New York, Fress press. 87p.

26) Rogers, K. (2009). Understanding e-marketing: marketing strategies for engaging the digital

27) Siudek, T and Zawojska A. (2014). Competitiveness in the economic concepts, theories and empirical research. Warsaw University of Life Sciences Oeconomia 13(1): 91-108

28) Smith, P. R. and Chaffey, D. (2005). E-Marketing excellence: the Heart of eBusiness. Elsevier/Butterworth-Heinemann, Amsterdam, 54p.

29) Sullivan, O. and Dooley, L.(2009). Applying Innovation. Los Angeles: Sage Publication, 54p.

30) Taiwo, A.S. (2010). Strategic marketing strategies on the performance of firms in Nigerian oil and gas industry. Journal of Emerging Trends in Economics and Management sciences 1(1): 23-36.

31) Wilson, V and Makau, C (2017) Online Marketing Use: Small and Medium Enterprises (smes) Experience from Kenya. ORSEA Journal, Vol. 7 (2), 63-77 